\author{
Analysis of drugs \\ Рекомендована д. фрарм. н., профр. В. А. Георгіянц \\ UDC 615.072:615.322:582.688.3-035.26 \\ $\mathrm{DOI}$

\section{DEVELOPMENT OF PHENOLIC COMPOUNDS CHROMATOGRAPHIC IDENTIFICATION IN BILBERRY SHOOTS}

\author{
CL. V. Vronska, M. B. Chubka, A. E. Demyd \\ SHEI "Ternopil State Medical University by I. Ya. Horbachevsky of MPH Ukraine"
}

Summary: the methodology of bilberry shoots officinal herbal raw material identification by the method of thin layer chromatography was developed. It was proposed to perform the identification by the means of the appearance of chromatographic profile of the raw material methanol withdrawal comparison with the standard zones of rutin position, chlorogenic acid, hyperoside and quercitrin. The formic acid - water - ethyl acetate (6: 9: 90) mixture was proposed as the aimed mobile phase.

Key words: bilberry shoots, identification, TLC, HPLC, quercitrin, chlorogenic acid, rutin, hyperoside.

Introduction. Bilberry shoots have hypoglycemic properties and are used for easy forms of diabetes as in the form of plant raw materials and as part of various charges, such as Arfazetyn and others [1-4]. Hypoglycaemic activity of bilberry fruit extract, rich in phenolic compounds, was shown on the model of streptozotocin diabetes in mice [5]. A number of other types of activity, such as antiradical, antineoplastic and anti-inflammatory are well studied concerning bilberry fruit and its extracts [5-7]. Hypoglycaemic properties of fruit are associated with phenolic compounds content, including anthocyanins [5, 8].

Shoots of bilberries are considered as herbal substance that contains tannins, although their presence is not associated with mild hypoglycaemic effect. It is known that the leaves of bilberry contain tannins, hydroxycinnamic acids, flavonoids, triterpene acids and vitamins. The highest content of phenolcarboxylic acids and flavonoids is observed for shoots harvested in summer, while the content of catechins and tannins is higher for raw materials harvested in autumn [9]. Qualitative and quantitative composition of flavonoids and hydroxycinnamic acids of bilberry shoots was investigated in numerous works [8, 10-13].

Standardization of bilberry shoots as herbal substances is still going to be important because it is still little studied and in the State Pharmacopoeia of Ukraine there is no corresponding monograph. Manufacturers of bilberry shoots officinal herbal raw material perform their identification by means of a quality reaction on tannins with ammonium iron (III) sulphate, which is a nonspecific method. Moreover, taking into consideration the literature data and a various biological activity hydroxycinnamic acids and flavonoids it is necessary to study their composition for raw materials growing within the territory of Ukraine.

The objective of our work was investigation of bilberry shoots phenolic compounds with the help of chromatographic methods, development of methodology of their identification, selection of identification markers.

Investigation methods. The qualitative composition of four bilberry shoots samples that were harvested in summer in the following regions: 1 - Transcarpathia, 2 - Ternopil, 3 - Volyn, 4 - Ivano-Frankivsk, and five samples of "Shoots of bilberries" therapeutic agent, produced in PLC "Liktravy", Zhytomyr city was investigated.

The qualitative composition of phenolic compounds was studied by the methods of thin layer and high performance liquid chromatography. Chromatographic plates Silica gel $60 \mathrm{~F}_{254}$ ("Merck", Germany), chromatographic chamber "CAMAG", an instrument for spotting Linomat 5 ("CAMAG", Switzerland), lamp for observing chromatograms in ultraviolet light "CAMAG" were used for investigations by TLC method. Agilent 1200 liquid chromatograph with diode array detector ("Agilent", the USA) was used for HPLC investigations.

Standard samples of caffeic and chlorogenic acids (Fluka), rutin, hyperoside, quercitrin, isoquercitrin, quercetin, kaempferol, luteolin, naringenin, isorhamnetin, myricetin and apigenin (Sigma, Fluka) were used for identification of phenolic compounds. Exact dispensing (3 mg of acids or aglycones and $5 \mathrm{mg}$ of flavonoids glycosides) of standard samples were dissolved in $10 \mathrm{ml}$ of methanol.

The tested solutions for TLC and HPLC investigations of glycoside forms of flavonoids were being prepared by boiling of $1 \mathrm{~g}$ of the powdered raw material with $25 \mathrm{ml}$ of methanol under reflux on a water-bath for 1 hour.

While investigating flavonoids glycosides the TLC chromatography was performed in two solvent systems: 1 - formic acid - water - ethyl acetate (6:9:90); 2 - formic acid - glacial acetic acid - water - ethyl acetate (7.5: $7.5: 17: 67.5) .5 \mu \mathrm{l}$ for standards and $15 \mu \mathrm{l}$ for the tested solutions were applied as $7,5 \mathrm{~mm}$ band. Solvent front passed over a path of $15 \mathrm{~cm}$ from the start.

The tested solutions for the same content of aglycone investigations were prepared by the following algorithm:

ISSN 2312-0967. Фармацевтичний часопис. 2015. № 3 
$1.1 \mathrm{~g}$ of the powdered raw material with $1 \mathrm{ml}$ of $5 \mathrm{~g} / \mathrm{l}$ methenamine solution, $40 \mathrm{ml}$ of acetone and $4 \mathrm{ml}$ of hydrochloric acid R1 have been boiled for 2 hours on a boiling water bath with reflux condenser; 2) the cooled mixture was filtered; 3 ) the filtrate was transferred into a porcelain cup and a solution was evaporated up to $10 \mathrm{ml}$; 4) the resulting solution was transferred in a separating funnel using $20 \mathrm{ml}$ of water; 5) the aglycone extraction was performed twice during 15 minutes using $15 \mathrm{ml}$ of ethyl acetate each time; 6 ) the ethyl acetate extractions were transferred into a separating funnel and washed with $50 \mathrm{ml}$ of water during $5 \mathrm{~min}$ each time; 7) the filtering of the resulting ethyl acetate extraction was performed through a paper filter with $5 \mathrm{~g}$ of sodium sulphate anhydrous into a porcelain cup; 8) the obtained organic extraction was carefully evaporated until dryness on a water bath at a temperature not higher than $50^{\circ} \mathrm{C}$; 9) the dry residue was washed with $10 \mathrm{ml}$ of methanol into a volumetric flask.

While investigating flavonoids aglicones by TLC methods such mobile phases were used: 1 - chloroform - acetic acid (5:2); 2 - benzol - methanol (8:2); 3 - chloroform - methanol - methyl-ethyl ketone - acetyl acetone (70:10:5:1). $5 \mu \mathrm{l}$ for standards and $15 \mu \mathrm{l}$ for the tested solutions were applied with $7,5 \mathrm{~mm}$ band. Solvent front passed over a path of $15 \mathrm{~cm}$ from the start.

The plate was being heated to $100^{\circ} \mathrm{C}$ for $3 \mathrm{~min}$. Then chromatograms observation was performed in ultraviolet light with a wave-length of $365 \mathrm{~nm}$ after their sequential processing with $10 \mathrm{~g} / \mathrm{l}$ solution of diphenylboric acid aminoethyl ester and $50 \mathrm{~g} / \mathrm{l}$ solution of macrogol in methanol.

Conditions of HPLC analysis were the same for the tested solutions of glycosides and flavonoids aglycones:

Test solution. $5 \mathrm{ml}$ of samples stock solution (test solution for TLC) made up to $100 \mathrm{ml}$ with the mobile phase A.

Reference solution. $5 \mathrm{ml}$ of standards stock solution (reference solution for TLC) made up to $100 \mathrm{ml}$ with the mobile phase $A$.

Column:

- XTerra C 18 (Waters), stationary phase: octadecylsilyl silica gel for chromatography $(5 \mu \mathrm{m})$;

- size: I = $250 \mathrm{~mm}, \varnothing 4,6 \mathrm{~mm}$.

Mobile phase:

- mobile phase A: $0.6 \mathrm{~g}$ of sodium dihydrogen phosphate monohydrate dissolve in $1000 \mathrm{ml}$ of water for chromatography, adjusted $\mathrm{pH}$ with phosphoric acid to 2.5 (potentiometrically).

- mobile phase $B$ : acetonitrile.

Flow rate. $1.0 \mathrm{ml} / \mathrm{min}$ with the gradient:

$\begin{array}{ccc}\text { Time, min } & \begin{array}{c}\text { Mobile phase A } \\ (\% \mathrm{~V} / \mathrm{V})\end{array} & \begin{array}{c}\text { Mobile phase B } \\ (\% \mathrm{~V} / \mathrm{V})\end{array} \\ 0-5 & 90 & 10 \\ 5-27 & 90 \rightarrow 80 & 10 \rightarrow 20 \\ 27-28 & 80 \rightarrow 50 & 20 \rightarrow 50 \\ 28-30 & 50 & 50 \\ 30-40 & 50 \rightarrow 90 & 50 \rightarrow 10 \\ 40-55 & 90 & 10\end{array}$

Detection: spectrophotometer at the wavelength of $330 \mathrm{~nm}, 370 \mathrm{~nm}$.

Injection. $50 \mu \mathrm{L}$.

Results and discussion. The results of glycoside flavonoids forms and phenolcarboxylic acids identification in two solvent systems are shown in table 1 . The following conclusions can be done analyzing the obtained data: bilberry shoots contain chlorogenic acid mostly from phenolcarboxylic acids, the caffeic acid appears on the chromatograms as a zone with weak fluorescence intensity.

In both solvent systems three located next to each other flavonoids zones with an average intensity of fluorescence are shown at the top of the chromatogram; the central of these zones is identified as a quercitrin.

Isoquercitrin appears on chromatograms of all samples as a zone of very weak fluorescence and hyperoside - with an average fluorescence. Under a zone of chlorogenic acid in the first solvent system and over a zone of chlorogenic acid in the second solvent system, much more hydrophilous, flavonoid glycoside appears as the most intensive fluorescence area. Another flavonoid with a large intensity of fluorescence appears over rutin zone in both solvent systems. Flavonoids aglycones were not found in methanol extractions of bilberry shoots in the described conditions.

When choosing a solvent system for determining the nature of the studied flavonoids aglycones, their mobility in three mobile phases studies were performed. Results of the mobility factors and colouring zones of various aglycones studied are presented in table 2 .

The third mobile phase was chosen as optimal for separation of the chosen aglycones flavonoids since it allows us to identify separately kaempferol and isorhamnetin that have almost the same fluorescence colouring and close location of zones.

The flavonoids aglycone content studying of nine bilberry shoots samples allowed to identify aglycones: quercetin as a zone of very intense orange fluorescence and kaempferol as a zone of weak yellow-blue fluorescence. In the described sample processing conditions there are other fluorescent zones on the TLC chromatogram. Thus, the main bilberry shoots aglycone of flavonoids, which grows within the territory of Ukraine and is industrially stored up, is quercetin.

As described for HPLC chromatographic conditions nine selected samples of bilberry shoots were investigated. Examples of chromatograms for the tested solutions of some regional and industrial samples are shown in Figures 1 and 2.

The results of TLC about the presence of quercitrin, hyperoside, traces of rutin, as well as chlorogenic and traces of caffeic acid in significant amount in all studied samples of bilberry shoots were confirmed by HPLC analysis. HPLC investigation of bilberry shoots samples after hydrolysis confirms the presence of quercetin as a dominant aglycone and traces of kaempferol.

ISSN 2312-0967. Pharmaceutical review. 2015. № 3 


\section{Analysis of drugs}

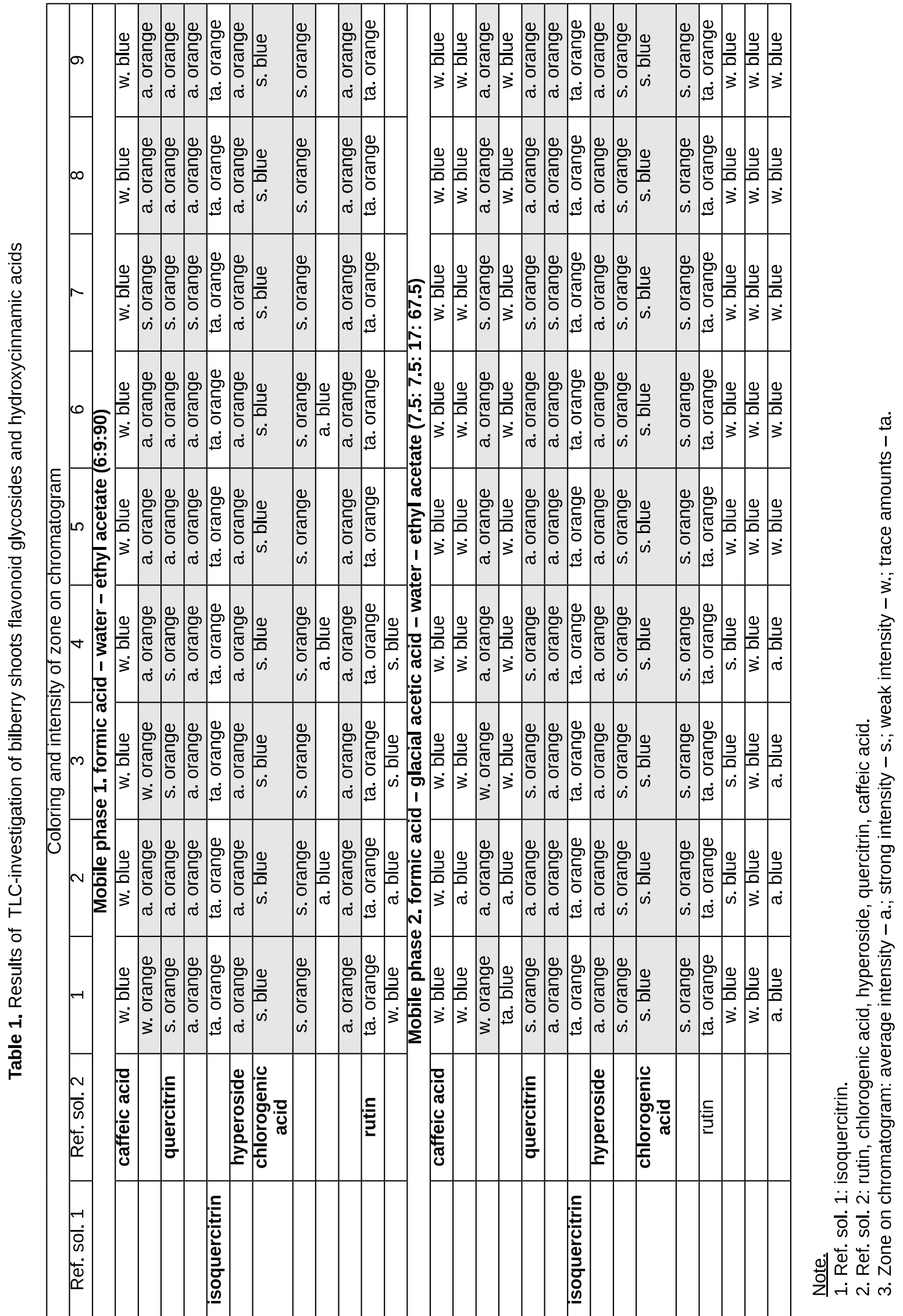


Table 2. Chromatographic properties of aglycone in different solvent systems

\begin{tabular}{|c|c|c|c|c|}
\hline \multirow{2}{*}{ Aglycone } & \multirow{2}{*}{ The color zones } & \multicolumn{3}{|c|}{ Dimension of $\mathrm{R}_{\mathrm{f}}$ in mobile phase } \\
\cline { 3 - 5 } & & 1 & 2 & 3 \\
\hline myricetin & orange & 0,09 & 0,14 & 0,10 \\
\hline quercetin & orange & 0,20 & 0,29 & 0,29 \\
\hline luteolin & yellow & 0,24 & 0,31 & 0,34 \\
\hline apigenin & yellow-green & 0,38 & 0,44 & 0,50 \\
\hline kaempferol & yellow-blue & 0,39 & 0,45 & 0,53 \\
\hline isorhamnetin & yellow-blue & 0,41 & 0,44 & 0,58 \\
\hline naryngenin & blue & 0,48 & 0,50 & 0,56 \\
\hline
\end{tabular}

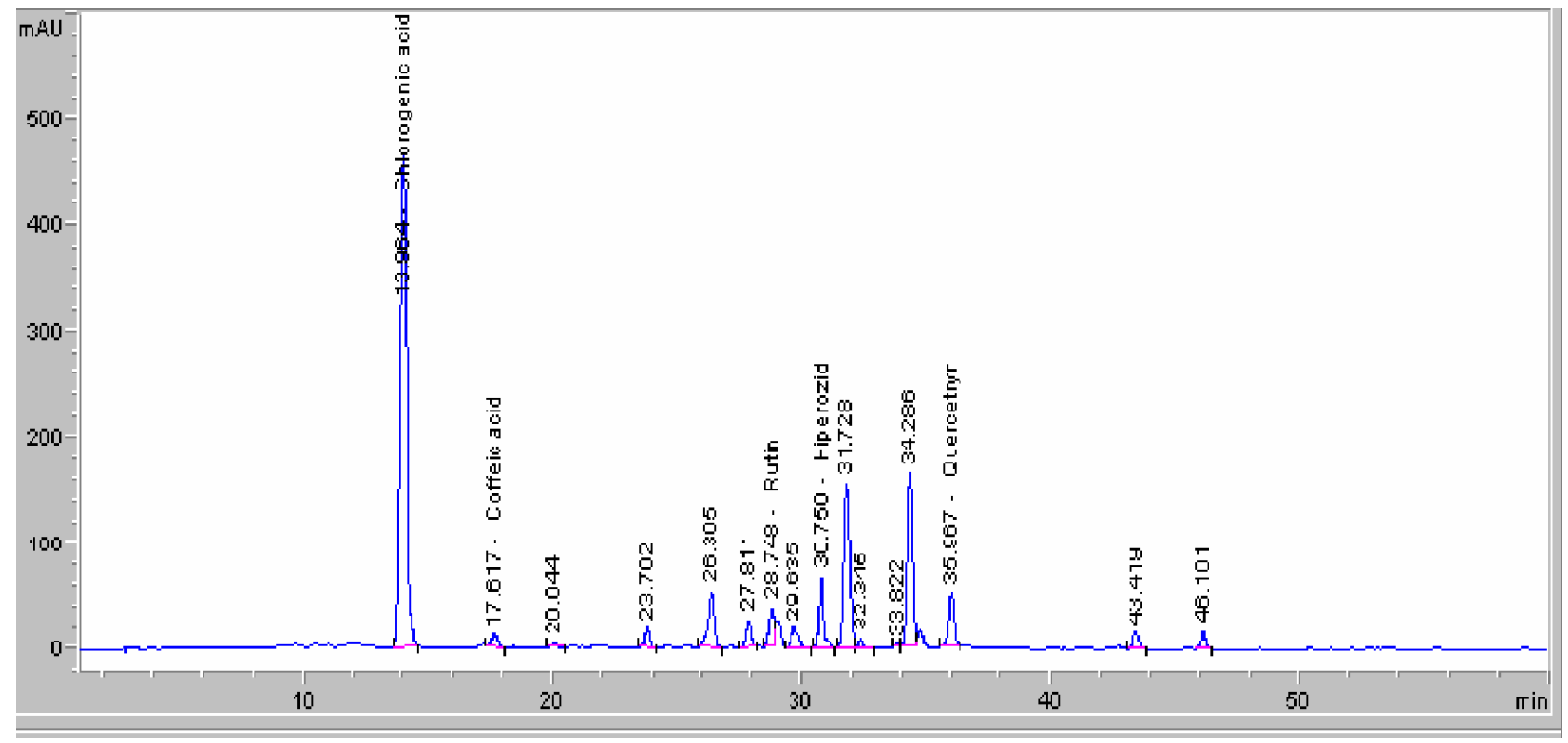

Fig. 1. HPLC-chromatogram of Ternopil region raw material test solution $(\lambda=330 \mathrm{~nm})$.

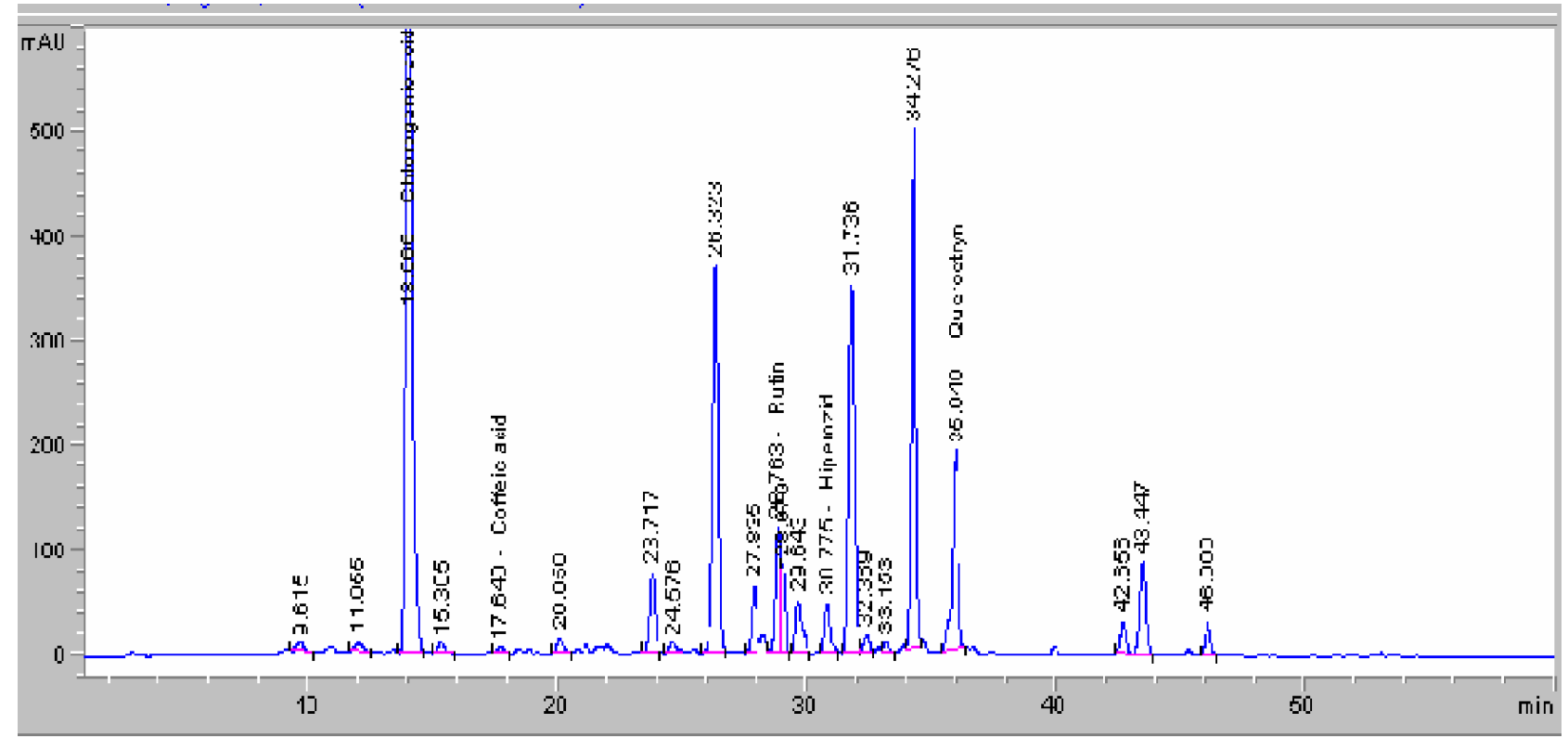

Fig. 2. HPLC-chromatogram of industrial series of raw materials (sample 7) test solution ( $\lambda=330 \mathrm{~nm}$ ).

ISSN 2312-0967. Pharmaceutical review. 2015. № 3 


\section{Analysis of drugs}

The obtained data from investigations of phenolic compounds qualitative content of Ukrainian bilberry shoots samples indicate a difference from raw material samples that were investigated and described earlier $[12,13]$. The main representative of bilberry shoots flavonoids according to [12] is hyperoside, and according to [13] - rutin. In the investigated Ukrainian samples six flavonoids glycosides are presented two of which (unidentified) are with intense fluorescence zones between the rutin and chlorogenic acid zones - hyperoside and quercitrin, and the other two - (unidentified) that are placed under and over the quercitrin zone. Conditions of TLC-identification of bilberry shoots were proposed by [10] authors; caffeic acid and quercetin-3-O- $\beta$-Dksylopyranozyd have been identified among 4 defined phenol compounds.

The difference between Ukrainian samples analysis results and data of [10-13] authors is obviously caused by not only differences in sample preparation and sensitivity of the methods used, but also indicates the quality different from bilberry shoots phenolic compounds that grow in different conditions.

Therefore, TLC identification method of bilberry shoots was developed for medicinal plants growing in Ukraine.
Method of bilberry shoots phenolic compounds identification.

Test solution. Place $1.0 \mathrm{~g}$ of the powdered drug in a $50 \mathrm{ml}$ flask and add $25 \mathrm{ml}$ of methanol. Heat under a reflux condenser on a water-bath for 1 hour. Allow to cool and filter.

Reference solution. Disolve $3 \mathrm{mg}$ of the chlorogenic acid, $5 \mathrm{mg}$ of rutin, $5 \mathrm{mg}$ of hyperoside, $5 \mathrm{mg}$ of quercitrin in $10 \mathrm{ml}$ of methanol.

Plate: TLC silica gel plate.

Mobile phase: formic acid, water, ethyl acetate (6:9:90 V/V).

Application: $15 \mu \mathrm{L}$, as $7,5 \mathrm{~mm}$ bands.

Development: over a path of $15 \mathrm{~cm}$.

Drying: in air.

Detection: heat at $100^{\circ} \mathrm{C}$ for $3 \mathrm{~min}$; spray the plate whilst still hot with a $10 \mathrm{~g} / \mathrm{l}$ solution of diphenylboric acid aminoethyl ester in methanol and then with a $50 \mathrm{~g} / \mathrm{l}$ solution of macrogol 400 in methanol; allow to dry in air for about $30 \mathrm{~min}$; examine in ultraviolet light at $365 \mathrm{~nm}$.

Results: see below the sequence of zones present in the chromatograms obtained with the reference solution and the test solution. Furthermore, others faint zones may be present in the chromatogram obtained with the test solution.

\begin{tabular}{|c|c|}
\hline \multicolumn{2}{|c|}{ Top of thepliate } \\
\hline Quercitim: a light yollow zons & $\begin{array}{l}\text { a yellow zone (average intensity) } \\
\text { a yollow zone (avorago intonsity) } \\
\text { a yellow zone (average intensity) }\end{array}$ \\
\hline $\begin{array}{l}\text { Hyperoside: a light yellow zone } \\
\text { Chlorogenic arid a light blue zone }\end{array}$ & $\begin{array}{l}\text { yellow zone } \\
\text { a blue rone (very intensity) } \\
\text { a yellow zone (very intensity) }\end{array}$ \\
\hline Ruain a lighl yelluw zont & $\begin{array}{l}\text { a yellow zone (avenage intensity) } \\
\text { a wetk ytlluw zuit }\end{array}$ \\
\hline Reference solution & Test solution \\
\hline
\end{tabular}

Fig. 3. Type of the TLC chromatogram in the conditions of bilberry shoots identification.

\section{Conclusions.}

All bilberry shoots analyzed samples contain the rutin, chlorogenic acid, hyperoside, quercitrin, that have been identified with the help of TLC and HPLC methods.

TLC identification method of bilberry shoots was de- veloped and these compounds were proposed as identification markers.

Caffeic acid and isoquercitrin are contained in the studied samples of raw materials in small quantities, so they aren't recommended as obligatory identification markers.

ISSN 2312-0967. Фармацевтичний часопис. 2015. № 3 


\section{Literature}

1. Державний реєстр лікарських засобів України http:// www.drlz.kiev.ua

2. Пат. UA 102473 C2. A23F 3/34. Композиція фріточаю "Оздоровчий" / Іванова В. Д., Каряка Н. С., Ясинська І. Л.; заявл. 06.04.2012 ; опубл. 10.07.2013, Бюл. № 13. Іванова В.Д.

3. Пат. UA 86475 U. A23F 3/34, A61K 36/00. Фіточай гіпоглікемічний з яконом / Міщенко Л. Т., Дуніч А. А., Дащенко А. В., Остапченко Л. І., Весельський С. П., Преображенська Т. Д.; заявл. 02.09.2013 ; опубл. 25.12.2013, Бюл. № 24.

4. Пат. RU 2137491. А61K35/78. Диабетический сбор / Суханов А. И.; заявл. 14.05.1998; опубл. 20.09.1999.

5. Herbal Medicine: Biomolecular and Clinical Aspects. Chapter 4. Bilberry (Vaccinium myrtillus L.) / [Wing-kwan Chu, Sabrina C. M. Cheung, Roxanna A. W. Lau, and Iris F. F. Benzie ] ; Benzie IFF, Wachtel-Galor S, editors. [2 ${ }^{\text {nd }}$ edition]. - Boca Raton (FL): CRC Press. - 2011. [режим доступу http://www.ncbi.nlm.nih.gov/books/ NBK92770/\#ch4_51\#ch4_51].

6. Дослідження антиоксидантних властивостей екстрактів 3 нетрадиційної рослинної сировини / В. Д. Іванова, Н. С. Каряка // Наукові праці НУХТ. - 2011. - № 37. - C. 89-95.

7. Induction of Apoptosis in Cancer Cells by Bilberry (Vaccinium myrtillus) and the Anthocyanins / Naomi Katsube, Keiko Iwashita, Tojiro Tsushida [and oth.] // Japan
J. Agric. Food Chem. - 2003. - № 51 (1). - P. 68-75.

8. КуркинВ.А.Новыеподходывобластистандартизации сырья и препаратов черники обыкновенной/В. А. Куркин, Т. К. Рязанова // Извест. Самарского научн. центра РАН. - 2011. - T. 13, № 1(8). - C. 2010-2014.

9. Line Nybakken. Increased growth and phenolic compounds in bilberry (Vaccinium myrtillus L.) following forest clear-cutting / Line Nybakken, Vidar Selas Mikael Ohlson // Scandinavian J. of Forest Research. - 2013. V. 28, Iss. 4. - P. 319-330.

10. Рязанова Т. К. Фармакогностическое исследование плодов и побегов черники обыкновенной / Т. К. Рязанова // Фундаментальные исследования. - 2013. - № 8. C. $1136-1140$.

11. Рязанова Т. К. Новые подходы к комплексному использованию плодов и побегов черники обыкновенной / Т. к. Рязанова, В. А. Куркин // Извест. Самарского научн. центра РАН. - 2012. - Т. 14, № 5(3). - С. 754-757.

12. Мечникова Г. Я. Валидация методики количественного определения суммы фрлавоноидов в побегах Vaccinium myrtillus L. / Г. Я. Мечникова, Н.в. Матюшенко, О. В. Смирнова // Башкирский химический журнал. 2013. - T. 20, № 2. - С. 66-71.

13. Петров Е. В. Разработка методики количественного определения содержания фрлавоноидов в побегах черники обыкновенной / Е.В.Петров // Бюллетень ВСНЦ СО РАМН. - 2010. - № 3(73). - С. 253-255.

\section{ВИВЧЕННЯ МОЖЛИВОСТІ ІДЕНТИФІКАЦІЇ ПАГОНІВ ЧОРНИЦІ ХРОМАТОГРАФІЧНИМ МЕТОДОМ ЗА СКЛАДОМ ФЕНОЛЬНИХ СПОЛУК}

\section{Л. В. Вронська, М. Б. Чубка, А. Є. Демид}

Тернопільський державний медичний університет імені І. Я. Горбачевського

Резюме: розроблена методика ідентифікації лікарської рослинної сировини пагонів чорниці методом тонкошарової хроматографії. Ідентифікацію запропоновано здійснювати шляхом порівняння вигляду хроматограсрічного просрілю метанольного вилучення сировини із положенням зон стандартів рутину, кислоти хлорогенової, гіперозиду і кверцитрину. Оптимальною рухомою фразою запропонована суміш formic acid - water - ethyl acetate (6:9:90).

Ключові слова: пагони чорниці, ідентисрікація, ТШХ, ВЕРХ, кверцитрин, кислота хлорогенова, рутин, гіперозид.

\section{ИЗУЧЕНИЕ ВОЗМОЖНОСТИ ИДЕНТИФИКАЦИИ ПОБЕГОВ ЧЕРНИКИ ХРОМАТОГРАФИЧЕСКИМ МЕТОДОМ ПО СОСТАВУ ФЕНОЛЬНЫХ СОЕДИНЕНИЙ}

\section{Л. В. Вронска, М. Б. Чубка, А. Е. Демид}

Тернопольский государственный медицинский университет имени И.Я. Горбачевского

Резюме: разработана методика идентификации лекарственного растительного сырья побегов черники методом тонкослойной хроматографии. Идентификацию предложено осуществлять путем сравнения видахроматографического профиля метанольного извлечения из сырья с положением зон стандартов рутина, кислоты хлорогеновой, гиперозида и кверцитрина. Оптимальной подвижной фазой предложена смесь муравьиная кислота - вода - этилацетат (6: 9: 90).

Ключевые слова: побеги черники, идентификация, ТСХ, ВЭЖХ, кверцитрин, кислота хлорогеновая, рутин, гиперозид. 